The chart shows that Estonia invests the most in Ukraine, its FDI exceeds Latvia's FDI by almost 8 times. It should also be noted that in 2017, investments from all countries in Ukraine decreased slightly. The number of Lithuanian investors has not increased in recent years. Unfortunately, for these countries of the Baltic region, Ukraine is not a priority for investment.

Thus, the global Covid-19 pandemic has really had a significant impact on the development of economic relations between Ukraine and Latvia, Lithuania and Estonia. Most of these negative effects were manifested in a decrease in exports and imports in these countries. However, because of the fact that Ukraine is not a priority trading partner for these Baltic countries, they have not suffered much from the decline in Ukrainian imports. Moreover, due to the fact that Ukraine does not inspire confidence in investors of the studied countries and attracts small amounts of foreign direct investment, the pandemic will not greatly affect their further dynamics.

\author{
References: \\ 1. Derzhavna sluzhba statystyky Ukrainy. Available at: \\ http://www.ukrstat.gov.ua/operativ/menu/menu_u/zed.htm
}

\title{
COMPETITIVE ADVANTAGES OF ORGANIC PRODUCTS: THE ESSENCE AND SOURCES OF THEIR FORMATION
}

\section{Marina Kotsenko ${ }^{1}$}

DOI: https://doi.org/10.30525/978-9934-26-002-5-27

The production development and increasing the competitiveness of enterprises in the world market is an important stage in the formation of the Ukrainian economy. One of the main methods of ensuring the competitiveness of the enterprise is to identify, ensure, maintain and increase competitive advantage. Organic production is no exception. More and more agricultural producers are studying the introduction and development of organic products. Considering the trends of foreign agronomists and producers, organic production is becoming not only a way to earn and develop business, but also a conscious choice in favor of ensuring the growth of a healthy nation.

Organic products become an important indicator not only in Ukrainian economy, but also in increasing the socio-economic status of the state on the

${ }^{1}$ Polissya National University, Ukraine 
world stage. According to FiBL (Research Institute of Organic Agriculture), the market for organic products in Ukraine is constantly growing. The area of agricultural lands used in organic production is increasing, namely for the last 5 years their area has increased 1.5 times and amounts to 309 thousand hectares. The number of products sold in Ukraine in 2018 is 6.7 thousand tons of organic products, and the largest part of it is dairy products -4.4 thousand tons. Ukrainian organic products are also represented and sold on world markets in more than 35 countries. These include European countries (Latvia, Germany, the UK, the Netherlands), North America and Asia [7].

Therefore, the feasibility of increasing the production of organic products and the development of organic production in the opinion of the Federation of Organic Movement in Ukraine include the following factors: maintaining soil fertility; increasing the development of agriculture, and with it the development of rural areas; ensuring food security and sustainable development in the country; raising the socio-economic image of Ukraine on the world stage; increase in product exports; improving the general kindness of Ukrainians [6].

All that gives Ukrainian entrepreneurs a confident start to the production of environmentally friendly products using only organic fertilizers and preserving the environment. The introduction and development of organic production primarily requires the establishment of competitive advantages of organic products. To do this, we must first clearly understand what includes the concept of «competitive advantage of organic products».

A number of foreign and domestic scientists have dealt with the issue of defining the essence of this concept. Some interpretations may have some differences. One of the first to define the concept of «competitive advantage» was the American economist Michael Porter. In his work «Competition» he points out the following: «Competitive advantages essentially arise from the value that the company is able to create for its customers and which exceeds the cost of its creation. Cost is what buyers are willing to pay: high cost is due either to a lower price level compared to the price of competitors for a similar product, or the provision of unique benefits that rehabilitate a higher price» [5, p. 160].

In this definition, competitive advantage is considered as a consumer advantage. So, the company offers goods either at a lower cost or at a higher cost, but offering a higher quality product. But in both cases, value will be defined as the main component of competitiveness that can not be used in the manufacture of organic products, because organic products will have a higher price than conventional products.

Russian scientist Gennady Azoev believes that competitive advantage is a concentrated manifestation of advantage over competitors in economic, technical, organizational areas of the enterprise, which can be measured by 
economic indicators (additional profit, higher profitability, market share, sales, etc.) [1, p. 16].

Ukrainian scientists also had their own vision of the essence of competitive advantages. These include Liudmyla Balabanova, Anatoly Voychak, and N. Zadorozhna. And yes, A. Voychak suggests considering competitive advantages as characteristics or properties that provide the company with advantages over competitors [3, p. 50]. L. Balabanova characterizes competitive advantage as the strengths of the enterprise that are able to provide an advantage over competitors [2, p. 22]. According to $\mathrm{N}$. Kudenko, competitive advantage is an indicator that provides superiority to competitors in the target market, and it provides the company with a unique competitive position. It must also be stable, so the company could hold for some time; challenging for copying by competitors and followers; should provide the highest possible profitability within the target industry. It must also have its own life cycle, which holds the stages of formation, successful use and loss of competitive advantage [4, p. 104].

Exploring the definition of the concept and essence of competition advantage, we have come to the conclusion that there is no single definition. We also have determined that the competitive advantage of organic products is a set of factors and properties that provide a certain advantage over competitors. The competitive advantages of organic products are a number of factors and features that allow the company to produce organic products better than its competitors, and using available resources. These factors directly affect the profitability of the enterprise.

To obtain certain competitive advantages, the company needs to take into account the sources of their formation. Establishing sources of formation will give the ability to ensure the existence of these competitive advantages. There are many approaches to systematization and study of sources of competitive advantage. Analyzing them, we have identified some sources:

- innovative sources, which are very important for the development of organic production, as the transition from conventional to organic production needs a number of changes that are not possible without innovation;

- geographical sources, including the state of availability of agricultural land and soil fertility. Organic production is not possible without a sufficient amount of land that meets European standards for the manufacture of organic products. Geographical location of the enterprise is extremely important, as well as how close it is to transport sales channels;

- production sources, which should include the search for methods to reduce costs, labor productivity, distribution and use of fixed assets and provision of material and technical resources; 
- management sources, which include a large number of factors. For example, such as personnel management, working capital management, compliance with the existing management system at the enterprise, the quality of procurement and product sales;

- economic sources, which are undoubtedly the most important in the formation of organic products competitive advantages. We can include here solvency of the enterprise, availability of sources of financing, possibility of investment attraction, profitability and profitability;

- conjunctural sources are market conditions of activity of the enterprise and a condition of competitive environment (the presence of aggressive competitors, and the state of competitiveness of the enterprise itself in the industry);

- communication and information sources, including the accessibility of information about products and the enterprise, as well as general ideas of consumers about enterprise.

The research about the organic production development by determining the competitive advantages of organic products will allow enterprises to grow. In the future it will be necessary to analyze all the available methods and models for determining competitive advantages. We will also need to look for new ways for increasing the competitiveness of domestic manufacturers of organic products.

\section{References:}

1. Azoev, Gh. L., \& Chelenkov, A. P. (2000). Konkurentnye preymushhestva firmy [Competitive advantages of the firm]. Moscow, $459 \mathrm{p}$.

2. Balabanova, L. V., \& Krivenko, A. V. (2014). Upravlenie konkurentosposobnostyu predpriyatiya na osnove marketinga [Competitiveness predpriyatiya on the basis of marketing]. Donetsk: DonGUET them. M. TuganBaranovsky, $147 \mathrm{p}$.

3. Vojchak, A. V., \& Kamyshnikov, R. V. (2005). Konkurentni perevaghy pidpryjemstva: sutnistj i klasyfikacija [Competitive advantages of the enterprise: essence and classification]. Marketing in Ukraine, vol. 2, pp. 50-53.

4. Kudenko, N. V. (2002). Marketynghovi strateghiji firmy [Marketing firm strategy]. Monograph. Kyiv: KNEU, 245 p.

5. Porter, M. (2001). Konkurencyja [Competition]. Textbook. Moskow: «Williams», $495 \mathrm{p}$.

6. Federecija orghanichnogho rukhu Ukrajiny. Available at: http://organic.com.ua/ doczilnist-rozvytku-v-ukrayini

7. Forschungsinstitut für biologischen Landbau. Available at: http://organic.com.ua/organichni-produkti 